\section{Irradiance Level and Duration Required to Terminate the Dormancy of Begonia $\times$ semperflorens Seed}

\author{
William J. Carpenter ${ }^{1}$, Eric R. Ostmark ${ }^{2}$, and John A. Cornell ${ }^{3}$ \\ Environmental Horticulture Department, Institute of Food and Agricultural \\ Sciences, University of Florida, Gainesville, FL 32611
}

Additional index words. Begonia Xsemperflorens-cultorum, seed photodormancy, lighting intensity, delayed germination, irregular germination

\begin{abstract}
Begonia Xsemperflorens-cultorum Hort. 'Prelude Scarlet' seeds varied within irradiance treatments in the irradiance level and duration that they required to reach the light saturation value and germinate. At high photosynthetically active radiation (PAR), seeds required light for only part of the germination period to terminate photodormancy. Germination $>90 \%$ was achieved after 4 and 1 day of 24 hours/day exposure to PAR at 15 and $150 \mu \mathrm{mol} \cdot \mathrm{m}^{-2} \cdot \mathrm{s}^{-1}$, respectively, but $82 \%$ germination occurred after 4 days of irradiance at $1.5 \mu \mathrm{mol} \cdot \mathrm{m}^{-2} \cdot \mathrm{s}^{-1}$ at $27 \mathrm{C}$. Fewer days to $50 \%$ of final germination $\left(T_{50}\right)$ and between $10 \%$ and $90 \%$ germination $\left(T_{90}-T_{10}\right)$ were required when light saturation was achieved after 1 day at high PAR rather than after 4 days at a low PAR level. The total PAR that seeds received during 6,12 , or 24 hours of light daily determined the total percentage of the seeds that germinated. Seeds receiving $150 \mu \mathrm{mol} \cdot \mathrm{m}^{-2} \cdot \mathrm{s}^{-1}$ continuously for $\geq \mathbf{2 4}$ hours achieved $90 \%$ germination, but 6 or 12 hours daily at this irradiance level required 4 days and 3 days, respectively. Trends in total germination percentages $(G), T_{50}$, or $T_{90}-T_{10}$ with increased PAR levels, hours of light daily, or days of light were found by fitted regression equations and Tukey's HSD procedure. Begonia seed germination was promoted by PAR levels of 1.5 to $150 \mu \mathrm{mol} \cdot \mathrm{m}^{-2} \cdot \mathrm{s}^{-1}$ for periods $\leq 4$ days, with darkness thereafter until cotyledon emergence.
\end{abstract}

Seed dormancy of many bedding plant species is terminated only after exposing hydrated seed to light. Fibrous-rooted begonia seed requires light for germination and is sown and germinated on the surface of uniformly moist mediums at 28 or 29C (Ball, 1985). Cathey (1976) reported continuous irradiance at $45 \mu \mathrm{mol} \cdot \mathrm{m}^{-2} \cdot \mathrm{s}^{-1}$ from cool-white fluorescent light promoted the germination of fibrousrooted begonia seed. According to Nagao et al. (1959), tuberous-rooted Begonia evansiana Andr. seed germinated when photoperiods were $\geq 12 \mathrm{~h}$ at $10.5 \mu \mathrm{mol} \cdot \mathrm{m}^{-2} \cdot \mathrm{s}^{-1}$ photosynthetically active radiation (PAR) for three or more cycles. The photocontrol of seed dormancy is varied and complex. Short light periods promote germination of some plant species, but continuous irradiance is required for others. Bewley and Black (1982) reported that seeds requiring light vary in their responses to total irradiant energy. Khan (1977) found diverse irradiance needs within seed lots of the same

Received for publication 25 July 1994. Accepted for publication 4 Nov. 1994. Florida Agriculture Expt. Station Journal Series no. R-0 3959. We acknowledge Ball Seed Co. (West Chicago, Ill.) as the our seed source. This research was sponsored partially by a grant from the Bedding Plants Foundation, Lansing, Mich. The cost of publishing this paper was defrayed in part by the payment of page charges. Under postal regulations, this paper therefore must be hereby marked advertisement solely to indicate this fact.

${ }^{1}$ Professor, Environmental Horticulture Dept. ${ }^{2}$ Laboratory Technician, Environmental Horticulture Dept.

${ }^{3}$ Professor, Statistics Dept. cultivar, with some seeds requiring only a few hours irradiance daily for germination and others needing many hours of continuous light. Carpenter et al. (1994) found that the light period duration required to achieve maximum germination of impatiens (Impatiens wallerana Hook. f.) seed varied with the irradiance level. Bewley and Black (1982) and Carpenter et al. (1994) noted that during the latter stages of germination, light delays lettuce (Lactuca sativa L.) and impatiens root emergence. Our research objectives were to make comparisons of begonia total germination and germination rates and of the uniformity of treatments having various irradiance levels, daily light periods, and light durations (days).

\section{Materials and Methods}

Lighting and seed germination procedures. 'Prelude Scarlet' begonia seeds from Ball Seed Co. (West Chicago, Ill.) were received 6 weeks dusted with $3 \alpha, 4,7,7 \alpha$-tetrahydro-2-[(trichloromethyl)thio]-1 $H$-isoindole-1,3 (2H)dione (captan). Treatments contained four 100seed replications, with replications germinated in individual 9-cm petri dishes on blue blotter paper 100 (Anchor Paper Co., Charlotte, N.C.) saturated with $6 \mathrm{ml}$ of distilled water. Seeds receiving 1.5 or $15 \mu \mathrm{mol} \cdot \mathrm{m}^{-2} \cdot \mathrm{s}^{-1}$ PAR were germinated in incubators (model 17-5RG; Stults Scientific Engineering Corp., Springfield, Ill.) equipped with $60-\mathrm{W}$ incandescent lamps, timeclocks to control the lighting durations, and dimmers (Lutron Co., Coopersburg, $\mathrm{Pa}$.) to establish light levels. Seeds receiving after harvest. Seeds in all treatments were
$\mathrm{PAR}$ at $150 \mu \mathrm{mol} \cdot \mathrm{m}^{-2} \cdot \mathrm{s}^{-1}$ were germinated in Conviron plant growth chambers (model E15; Controlled Environments, Winnipeg, Manitoba, Canada) with PAR at a 3:1 ratio from fluorescent and incandescent lamps, respectively. A quantum radiometer (model 18A; LICOR, Lincoln, Neb.) was used to monitor the PAR levels. In all treatments, seeds were germinated at constant $27 \mathrm{C}$, except in plant growth chambers where air was at $26 \mathrm{C}$ during lighting periods at $150 \mu \mathrm{mol} \cdot \mathrm{m}^{-2} \cdot \mathrm{s}^{-1}$.

Lighting treatments and data analysis. Imbibed seeds received $1.5,15$, or 150 $\mu \mathrm{mol} \cdot \mathrm{m}^{-2} \cdot \mathrm{s}^{-1}$ for $6,12,18$, or $24 \mathrm{~h}$ daily for 1 , 2,3 , or 4 days, then darkness. In light or darkness, daily counts of seed with emerged radicles were made. Seed kept in darkness were counted in $\operatorname{dim}$ light $\left(0.21 \mu \mathrm{mol} \cdot \mathrm{m}^{-2} \cdot \mathrm{s}^{-1}\right.$ from a $25-\mathrm{W}$ green lamp). Total germination percentages $(\mathrm{G})$, number of days to $50 \%$ final germination $\left(\mathrm{T}_{50}\right)$, and number of days between $10 \%$ and $90 \%$ germination $\left(\mathrm{T}_{90}-\mathrm{T}_{10}\right)$ were calculated from the data as described by Furutani et al. (1985). The data were tested statistically by analysis of variance (ANOVA) and regression (linear and quadratic) equations; the latter were used to determine if trends in the germination values had occurred with changes in light level and duration. The PAR intensity on germination interacted with the effect of lighting duration; therefore, separate equations were fitted at the three intensity levels to measure the effect of lighting duration in hours, days on germination, or both. Germination trends, across the light levels, were not easily discernible from the fitting of regression equations; thus, $\mathrm{G}, \mathrm{T}_{50}$, and $\mathrm{T}_{90}-\mathrm{T}_{10}$ comparisons of the mean values at three total PAR levels during 1, 2, or 4 days were made using Tukey's HSD procedure at $P \leq 0.05$ to determine where differences in means were present.

\section{Results}

PAR level and germination. Seed germination percentages increased as PAR increased from 1.5 to $150 \mu \mathrm{mol} \cdot \mathrm{m}^{-2} \cdot \mathrm{s}^{-1}$ and light period durations were lengthened from 6 to $24 \mathrm{~h}$ (Table 1). Seeds receiving $150 \mu \mathrm{mol} \cdot \mathrm{m}^{-2} \cdot \mathrm{s}^{-1}$ for 3 or 4 days achieved $\approx 90 \%$ G. Lower irradiance levels, short durations (i.e., $\leq 2$ days), or both resulted in lower $\mathrm{G}$. The increases in $\mathrm{G}$ at 15 and $150 \mu \mathrm{mol} \cdot \mathrm{m}^{-2} \cdot \mathrm{s}^{-1}$ were linear when 1 and 2-day lighting periods each were lengthened from 6 to $24 \mathrm{~h}$ (Table 1). No seeds germinated after receiving $1.5 \mu \mathrm{mol} \cdot \mathrm{m}^{-2} \cdot \mathrm{s}^{-1}$ for one 6- or one 12-h period (32.4 and 64.8 $\mathrm{mmol} \cdot \mathrm{m}^{-2}$ total PAR) (Table 1 ).

Linear decreases in the $T_{50}$ values occurred as the irradiance durations at 15 and 150 $\mu \mathrm{mol} \cdot \mathrm{m}^{-2} \cdot \mathrm{s}^{-1}$ were extended from 6 to $24 \mathrm{~h}$ (Fig. 1). The decrease rate in $T_{50}$ values at 150 $\mu \mathrm{mol} \cdot \mathrm{m}^{-2} \cdot \mathrm{s}^{-1}$ was slightly, but significantly $(P$ $\leq 0.05)$, greater than at $15 \mu \mathrm{mol} \cdot \mathrm{m}^{-2} \cdot \mathrm{s}^{-1}$ as determined by the $\mathrm{F}$ test described by Draper and Smith (1981). The total PAR levels at 15 $\mu \mathrm{mol} \cdot \mathrm{m}^{-2} \cdot \mathrm{s}^{-1}$ varied from 324 to $1296 \mathrm{mmol} \cdot \mathrm{m}^{-2}$ at 6- to 24-h irradiance, respectively, and from 3240 to $12,960 \mathrm{mmol} \cdot \mathrm{m}^{-2}$ at $150 \mu \mathrm{mol} \cdot \mathrm{m}^{-2} \cdot \mathrm{s}^{-1}$. Declines in the $\mathrm{T}_{90}-\mathrm{T}_{10}$ values were linear as 
the irradiance periods increased from 6 to $24 \mathrm{~h}$, but values were similar for seeds receiving 1.5 and $150 \mu \mathrm{mol} \cdot \mathrm{m}^{-2} \cdot \mathrm{s}^{-1}$ at each lighting duration (data not presented).

Daily hours of light exposure. The total PAR received by seeds during $6,12,18$, or 24 $h$ of light daily determined $G$. At each PAR level and daily duration, the germination percentage increased curvilinearly as the number of days of light increased (Table 1). Moreover, at each PAR level and number of days of light, G increased linearly with increased hours of daily light (Table 1). A maximum germination of $90 \%$ was achieved when seeds received $150 \mu \mathrm{mol} \cdot \mathrm{m}^{-2} \cdot \mathrm{s}^{-1}$ for 1 day. However, reaching 90\% germination at this PAR level applied for 6,12 , or 18 h daily required 4,3 , and 3 days, respectively (Table 1 ). Seeds irradiated at 15 $\mu \mathrm{mol} \cdot \mathrm{m}^{-2} \cdot \mathrm{s}^{-1}$ required 4 days to achieve $\approx 90 \%$ germination at all daily lighting durations. Seeds irradiated at $1.5 \mu \mathrm{mol} \cdot \mathrm{m}^{-2} \cdot \mathrm{s}^{-1}$ reached $\approx 82 \%$ germination only after continuous light for 4 days.

Days of light exposure. Seed G generally increased when the same total irradiance level was provided during more days of exposure. The exception was at $12,960 \mathrm{mmol} \cdot \mathrm{m}^{-2}$ where $\mathrm{G}$ was similar whether this total irradiance level was received during 1,2, or 4 days (Table 2). Begonia seed receiving $1296 \mathrm{mmol} \cdot \mathrm{m}^{-2}$ of irradiance during 1,2 , or 4 days had $\mathrm{G}$ values $>50 \%$, but $\mathrm{G}$ was between $20 \%$ and $60 \%$ at $129.6 \mathrm{mmol} \cdot \mathrm{m}^{-2}$ (Table 2). The $\mathrm{T}_{50}$ and $\mathrm{T}_{90}-\mathrm{T}_{10}$ values were significantly $(P \leq 0.05)$ higher for seeds receiving 129.6 than 1296 or 12,960 $\mathrm{mmol} \cdot \mathrm{m}^{-2}$. Seeds receiving $129.6,1296$, or $12,960 \mathrm{mmol} \cdot \mathrm{m}^{-2}$ total irradiance during 1 or 2 days generally had significantly lower $\mathrm{T}_{50}$ and $\mathrm{T}_{90}-\mathrm{T}_{10}$ values than when each total irradiance was received over 4 days (Table 2).

\section{Discussion}

The light-controlled germination responses found in our research previously have been associated with the action of phytochrome. We found that the PAR level and days of light during germination modified the $\mathrm{G}, \mathrm{T}_{50}$, and $\mathrm{T}_{90}-\mathrm{T}_{10}$ responses of begonia seeds. Bewley and Black (1982) reported that the effect of light is directly proportional to the total amount of energy received up to the saturation value, irrespective of how the energy is delivered. They stated that when the total light energy from irradiation level $\times$ time are equal, the percentage of seeds breaking dormancy and the germination rates associated with the treatments should be similar. We found that the light saturation value of begonia seeds varied with the PAR level received and the exposure period (days). Additional irradiance above the PAR saturation value needed to satisfy seed dormancy had no effect on $\mathrm{G}, \mathrm{T}_{50}$, or $\mathrm{T}_{90}-\mathrm{T}_{10}$ values.

Bedding plant cultivars requiring light for germination have been bred for morphological uniformity, but the individual seeds in our lot of 'Prelude Scarlet' begonia varied greatly in the PAR requirement for germination. No seeds germinated in total darkness, but before being held in total darkness, $8 \%, 21 \%, 40 \%$, and $53 \%$ germinated after one 6-, 12-, 18-, or 24-h irradiance period, respectively, at 15 $\mu \mathrm{mol} \cdot \mathrm{m}^{-2} \cdot \mathrm{s}^{-1}$. Lighting for longer durations at this PAR level or at higher levels promoted progressively higher $\mathrm{G}$.

Evenari (1965) stated the variability in seed response to light during germination was caused by the changes in seed phytochrome that results from illumination received during seed dehydration and rehydration. Frankland (1976) reported that phytochrome conversions occur in the seed while the mother plant matures and dries in light. Therefore, the mature seed from one pod or plant contains a mixture of phytochrome $\mathrm{P}_{\mathrm{R}}, \mathrm{P}_{\mathrm{FR}}$, and various intermediates. Bewley and Black (1982) found the

Table 1. Average germination percentage of begonia seed photosynthetic active radiation of $1.5,15$, and 150 $\mu \mathrm{mol} \cdot \mathrm{m}^{-2} \cdot \mathrm{s}^{-1}$ daily for $6,12,18$, or $24 \mathrm{~h}$ for 1 to 4 days at $27 \mathrm{C}$. Trends in germination percentages across hours daily and across numbers of days irradiated, as determined by regression analysis, are indicated.

\begin{tabular}{|c|c|c|c|c|c|c|c|}
\hline \multirow{3}{*}{$\begin{array}{l}\text { Irradiance level } \\
\left(\mu \mathrm{mol} \cdot \mathrm{m}^{-2} \cdot \mathrm{s}^{-1}\right)\end{array}$} & \multicolumn{5}{|c|}{ Germination (\%) } & & \\
\hline & \multicolumn{5}{|c|}{ Light (h/day) } & \multicolumn{2}{|c|}{ Significance } \\
\hline & $\overline{\text { Days }}$ & 6 & 12 & 18 & 24 & Linear & Quadratic \\
\hline \multirow[t]{3}{*}{1.5} & 1 & 0 & 0 & 11 & 19 & $*$ & NS \\
\hline & 2 & 12 & 23 & 34 & 57 & $* *$ & $*$ \\
\hline & 3 & 38 & 61 & 60 & 72 & $* *$ & NS \\
\hline Significance & 4 & 56 & 72 & 80 & 82 & $* *$ & NS \\
\hline Linear & & $* * *$ & $* * *$ & $* * *$ & $* * *$ & & \\
\hline Quadratic & & NS & $*$ & $* *$ & $* * *$ & & \\
\hline \multirow[t]{4}{*}{15} & 1 & 8 & 21 & 40 & 53 & $* * *$ & NS \\
\hline & 2 & 47 & 56 & 66 & 75 & $* *$ & NS \\
\hline & 3 & 79 & 84 & 86 & 80 & $*$ & $*$ \\
\hline & 4 & 91 & 92 & 91 & 91 & NS & NS \\
\hline \multicolumn{8}{|l|}{ Significance } \\
\hline Linear & & $* * *$ & $* * *$ & $* * *$ & $* * *$ & & \\
\hline Quadratic & & $* * *$ & $* *$ & $* *$ & $*$ & & \\
\hline \multirow[t]{4}{*}{150} & 1 & 34 & 38 & 74 & 90 & $* * *$ & NS \\
\hline & 2 & 61 & 88 & 86 & 87 & $* *$ & NS \\
\hline & 3 & 87 & 90 & 92 & 93 & NS & NS \\
\hline & 4 & 90 & 89 & 90 & 91 & NS & NS \\
\hline \multicolumn{8}{|l|}{ Significance } \\
\hline Linear & & $* * *$ & $* * *$ & $* *$ & NS & & \\
\hline Quadratic & & $* *$ & $* * *$ & $* *$ & NS & & \\
\hline $\mathrm{HSD}_{0.05^{\mathrm{Z}}}$ & 6 & & & & & & \\
\hline
\end{tabular}

${ }^{\text {zT}}$ Tukeys HSD for comparing the average germination percentages for the same day-hour combination at two photosynthetically active radiation levels.

Ns, ${ }^{*}, * *, * * *$ Nonsignificant or significant at $P \leq 0.1,0.05$, or 0.01 , respectively.

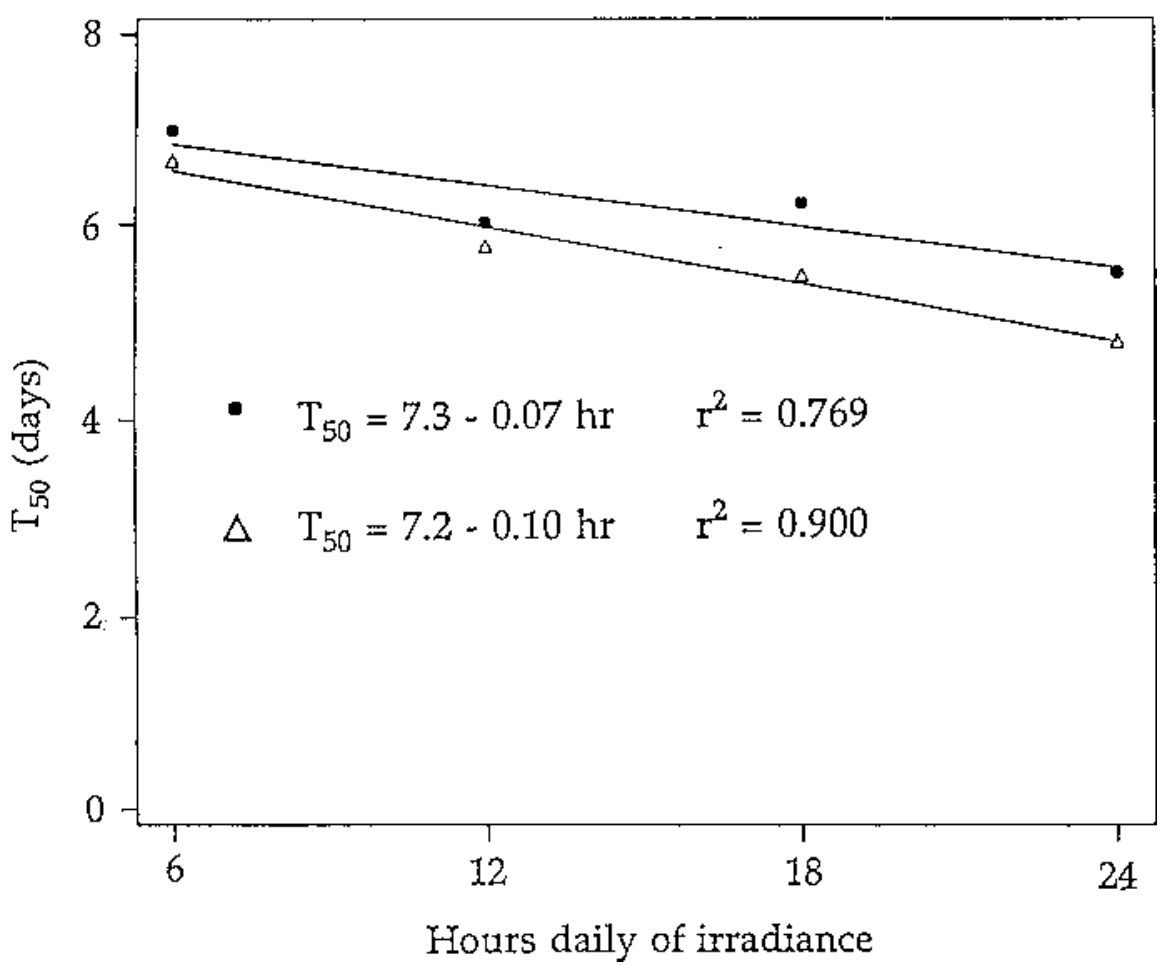

Fig. 1. Linear decreases in days to $50 \%$ final germination $\left(\mathrm{T}_{50}\right)$ occurred as the total irradiance begonia seeds received at $27 \mathrm{C}$ during one 6 - to one 24 -h lighting period increased at $15(\mathbf{O})$ and $150(\Delta) \mu \mathrm{mol} \cdot \mathrm{m}^{-2} \cdot \mathrm{s}^{-1}$ irradiance. Seeds received darkness following light treatment. Test for differences between slopes was significant at $P \leq 0.05$. 
proportions of phytochrome in each form depends on the spectral quality of the light received, the presence of surrounding chlorophyll, the duration and irradiance of light, and the time needed for seed rehydration. Evenari (1965) reported that the form of phytochrome at maturity of 'Grand Rapids' lettuce (Lactuca sativa L.) seed was preserved at moisture levels $<7 \%$ water for $\geq 1$ year.

These studies help us to understand better the frequent reports of low and irregular begonia seed germination. Ball (1985) and Cathey

Table 2. The effects of providing the same total irradiance $\left(129.6,1296\right.$, or $\left.12,960 \mathrm{mmol} \cdot \mathrm{m}^{-2}\right)$ during 1,2 , or 4 days at $27 \mathrm{C}$ on percentage of total germination $(\mathrm{G})$ of begonia, days to $50 \%$ of final germination $\left(\mathrm{T}_{50}\right)$, and span between $10 \%$ and $90 \%$ germination $\left(\mathrm{T}_{90}-\mathrm{T}_{10}\right)$. Data are means of four 100-seed replications during 28 days.

\begin{tabular}{lcccc}
\hline & & & & \\
Germination & $\begin{array}{c}\text { Total } \\
\text { irradiance } \\
\left(\mathrm{mmol} \cdot \mathrm{m}^{-2}\right)\end{array}$ & & \multicolumn{3}{c}{ Days } \\
\cline { 3 - 5 } response & 129.6 & 19 & 23 & 56 \\
\hline $\mathrm{G}$ & 1296 & 53 & 56 & 91 \\
& 12960 & 90 & 88 & 90 \\
$\mathrm{HSD}_{0.05}{ }^{\mathrm{z}}$ & 6 & & & \\
$\mathrm{~T}_{50}$ & 129.6 & 5.9 & 5.9 & 6.3 \\
& 1296 & 5.5 & 5.5 & 5.8 \\
& 12960 & 5.3 & 4.8 & 5.7 \\
$\mathrm{HSD}_{0.05}$ & 4 & & & \\
$\mathrm{~T}_{90}-\mathrm{T}_{10}$ & 129.6 & 2.5 & 3.1 & 3.3 \\
& 1296 & 2.0 & 2.2 & 2.5 \\
& 12960 & 1.9 & 1.9 & 2.4 \\
$\mathrm{HSD}_{0.05}$ & 0.3 & & &
\end{tabular}

Tukey's HSD for comparing two averages in a column or two averages in a row.
(1976) recommend light during germination of begonia seed, but they gave no guidelines for the irradiation level or lighting duration. The PAR required to reach the light saturation value and achieve maximum total germination and rapid and uniform germination varied among seeds in the same lot. These differences probably result from the form of phytochrome in the seed before germination. Seed exposure to low PAR levels for short durations daily may be adequate to promote the germination of some seeds but inadequate for other seeds to achieve the light saturation level required for germination. Thus, at low PAR levels, $\mathrm{G}$ is variable. Seeds receiving low PAR $\left(15 \mu \mathrm{mol} \cdot \mathrm{m}^{-2} \cdot \mathrm{s}^{-1}\right)$ daily during 4 days may achieve the light saturation level required for high total germination percentages, but germination will be delayed and more irregular. In our study, seeds receiving $1.5 \mu \mathrm{mol} \cdot \mathrm{m}^{-2} \cdot \mathrm{s}^{-1}$ PAR had higher $T_{50}$ and $T_{90}-T_{10}$ values than seeds receiving $150 \mu \mathrm{mol} \cdot \mathrm{m}^{-2} \cdot \mathrm{s}^{-1}$. Also, seeds that received $12,960 \mathrm{mmol} \cdot \mathrm{m}^{-2}$ total PAR during 1 and 4 days had $90 \% \mathrm{G}$, but lower irradiance during the longer lighting period increased $\mathrm{T}_{50}$ and $\mathrm{T}_{90}-\mathrm{T}_{10}$ values. Rapid and uniform begonia seed germination are becoming more important in commercial production. Based on our results, we recommend that begonia seeds receive light at $150 \mu \mathrm{mol} \cdot \mathrm{m}^{-2} \cdot \mathrm{s}^{-1}$ continuously for 1 or 2 days after moistening the germination substrate. Then, seed should be placed in darkness until cotyledon emergence. This darkness period will give high total germination and more rapid and uniform seedling emergence.

\section{Literature Cited}

Ball, V. 1985. Ball red book: Greenhouse growing. 14th ed. Reston Publishing Co., Reston, Va.

Bewley, J.D. and M. Black. 1992. Physiology and biochemistry of seeds. vol. 2. Viability, dormancy, and environmental control. SpringerVerlag, New York.

Carpenter, W.J., E.R. Ostmark, and J.A. Cornell. 1994. Light governs the germination of Impatiens wallerana Hook. f. seed. HortScience 29:854-857.

Cathey, H.M. 1976. Seed germination, p. 47-54. In: J.W. Mastalerz (ed.). Bedding plants, 2nd ed. Pennsylvania Flower Grower, University Park, $\mathrm{Pa}$.

Draper, N.R. and H. Smith. 1981. Applied regression analysis. 2nd ed. Wiley, New York.

Evenari, M. 1965. Light and seed dormancy, p. 804-807. In: W. Ruhland (ed.). Encyclopedia of plant physiology. vol. 15/2. Springer, Berlin.

Frankland, B. 1976. Seed irradiance, p. 477-492. In: H. Smith (ed.). Light and plant development. Butterworths, London

Furutani, S.C., B.H. Zandstra, and H.C. Price. 1985. Low temperature germination of celery seeds for fluid drilling. J. Amer. Soc. Hort. Sci. 110:149-153.

Khan, A.A. 1977. Preconditioning, germination and performance of seeds, p. 283-313. In: A.A. Khan (ed.). The physiology and biochemistry of seed dormancy and germination. North-Holland Publishing Co., Amsterdam, The Netherlands.

Nagao, M., Y. Esashi, T. Tanaka, T. Kumagi, and S. Fukumoto. 1959. Effects of photoperiod and gibberellin on the germination of seeds of Begonia evansiana Andr. Plant Cell Physiol. 1:39-47. 